Jurnal Belajar Bahasa, ISSN 2502-5864, E-ISSN 2503-0329

Volume 3, No. 2, September 2018

\title{
HASRAT KEPRIBADIAN TOKOH UTAMA DALAM NOVEL MEMBURU MATAHARI KARYA NADJIB KARTAPATI Z
}

\author{
Muhsyanur \\ STKIP Puangrimaggalatung Sengkang \\ muhsyanusyahrir85@gmail.com
}

\begin{abstract}
ABSTRAK
Penelitian ini bertujuan untuk mengungkapkan jenis hasrat kepribadian tokoh utama yang terdapat dalam novel Memburu Matahari karya Nadjib Kartapati Z. Teori yang digunakan dalam penelitian ini adalah teori skizoanalisis Deleuze dan Guattari. Jenis penelitian ini adalah deskriptif kualiatatif dengan menggunakan metode deskriptif analitis. Adapun pendekatan yang digunakan, yaitu pendekatan kepustakaan. Data penelitian ini diperoleh dari novel berupa kata, frasa, kalimat, atau penyataan yang berkaitan dengan fokus penelitian, yaitu tentang jenis hasrat kepribadian dari tokoh utama dalam cerita tersebut. Dari data yang diperoleh, kemudian dideskripsikan menurut jenis-jenis hasrat kepribadian yang ditemukan. Hasil penelitian ini menunjukkan bahwa hasrat kepribadian tokoh utama dalam novel Memburu Matahari karya Nadjib Kartapati Z adalah bahwa tokoh utama tersebut adalah seorang yang paranoid dan skizofrenik. Hasrat paranoid terbentuk dari status, tradisi, kepercayaan, keyakinan, nilai, dan ikatan darah (filiasi). Hasrat skizofrenik ditemukan ada dua yaitu tingkat individu dan makro. Penelitian menunjukkan bahwa kedua hasrat tersebut merupakan bagian dari skizoanalisis.
\end{abstract}

Kata-kata Kunci: hasrat kepribadian, paranoid, skizofrenik, skizo analisis

\begin{abstract}
This study aims to reveal the type of personality the main characters possesed in the novel Memburu Matahari by Nadjib Kartapati Z. The theory used in this research is the theory of skizoanalysis of Deleuze and Guattari. This research applied descriptive qualitative analytical descriptive method. The approach used is literature approach. The data of this research are obtained from novel in the form of words, phrases, sentences, or statements related to the focus of the research; that is about the types of personality possessed by the main characters. The obtained data are then described based on the types of personality possessed by the main characters. The results of this study indicated that the personalities of the main character in the novel Memburu Matahari by Nadjib Kartapati Z are paranoid and schizophrenic. Paranoid are formed by the status, tradition, faith, belief, value of norms, and blood bonding (filiation). The schizophrenic passions have two levels; first individual and macro levels.
\end{abstract}

Key Words: paranoid, personality desires, schizophrenic, schizo analysis

\section{PENDAHULUAN}

Novel merupakan salah satu jenis karya sastra berupa karangan prosa yang panjang karena memiliki alur dan rangkaian cerita kehidupan seseorang dengan orang lain. Bahkan segala sesuatu yang berhubungan dengan dunianya serta yang ada di sekelilingnya. Bentuk isi yang hendak disampaikan pengarang dalam karya sastra novel, tidak berbeda dengan karya sastra lainnya seperti puisi dan cerpen. Cerpen dan puisi memiliki bentuk isi berupa pesan yang hendak disam- 
Jurnal Belajar Bahasa, ISSN 2502-5864, E-ISSN 2503-0329

Volume 3, No. 2, September 2018

paikan si pengarang kepada pembaca. Demikian juga halnya dengan karya novel. Selain itu, cerpen dan puisi merupakan hasil proses ekspresi yang dituangkan ke dalam tulisan yang berisi cerita. Karya novel pun juga demikian. Pada umumnya karya sastra, baik novel, puisi, maupun cerpen merupakan memiliki sifat yang fiksi.

Fiksi karya Nadjib Kartapati Z yang dijadikan sumber data penelitian ini karena menghadirkan persoalan psikologis melalui tokoh-tokohnya. Data penenelitian ini memfokuskan pada novel Memburu Matahari yang diterbitkan pada tahun 2003. Novel tersebut menceritakan Ulfah sebagai isteri untuk memperjuangkan hak-hak yang dirampas karena keteguhan prinsip-prinsip suami. Novel Memburu Matahari memenangkan juara pertama perlombaan mengarang novel di Majalah Pertiwi. Burhan suaminya mengutamakan persoalan bangsa sehingga merasakan tersiksa selama pernikahan. Persoalan bangsa, yang meliputi kemiskinan, tingkat pendidikan yang rendah, sistem kebudayaan tidak kukuh, gaya hidup konsumtif, dan sekularisme. Ulfah secara ekonomi tidak dapat mengandalkan penghasilan suami yang bekerja di Lembaga Pembangunan Jakarta bahkan tidak digaji karena berorientasi perjuangan. Dengan demikian, Ulfah bekerja di perusahaan asing di bidang impor barang luks hasil teknologi maju. Mereka juga belum dikaruniai anak.

Merujuk pada cerita singkat yang dipaparkan tersebut, penelitian ini menggunakan teori skizoanlisis Deleuze dan Guattari. Gilles Deleuze filsuf, psikolog yang lahir tahun 1925 di Prancis. Felix Guattari aktivis politik, psikiatris, dan pemikir yang lahir 1930 di Prancis. Deleuze dan Guattari bekerja sama untuk membebaskan hasrat dari penalaran ego dan struktur sosial. Pemikiran Deleuze dan Guattari mendapat pengaruh dari nietzsche (Indriani, 2018, hal. 13).

Hal tersebut sejalan dengan pendapat Bertens (1998, hal. 90), Nietzsche termasuk filsuf yang berpengaruh atas kehidupan intelektual dalam abad 20. Pemikiran nietzshe memengaruhi perkembangan psikologi di kemudian hari. Nietzsche mengembalikan hasrat yang diabaikan dalam sejarah manusia dengan mengadili rasio. Pengadilan rasio untuk mengarahkan manusia pada alienasi. Alienasi terjadi karena individu mendapat penekanan dari stuktur sosial.

Deleuze dan mengkritik psikoanalisis yang disebabkan psikoanalisis tidak memasuki mesin hasrat setiap individu karena berpangkal pada struktur oedipal dan investasi libido sosial karena berpangkal pada investasi domestik. Freud menyempitkan hasrat hanya sebagai struktur oedipal. Freud menciptakan struktur oedipal untuk menangkap dan membunuh aliran hasrat. Struktur oedipal melahirkan subjek yang telah dihilangkan hasratnya dan masuk ke wilayah sosial. Deleuze dan Guattari membebaskan hasrat sehingga bergerak melampaui ruang dan waktu. Hasrat bersifat produktif yang menghasilkan aliran secara terus menerus sehingga penekanan akan melahirkan hasrat (Deleuze, G \& Guattari, 1977, hal. 20-21).. 

Jurnal Belajar Bahasa, ISSN 2502-5864, E-ISSN 2503-0329

Volume 3, No. 2, September 2018

Deleuze dan Guattari, Freud, dan Lacan berbeda dalam memandang istilah hasrat. Freud berbicara mengenai insting (Irawan, 2015, hal. 75). Insting berperan mengurangi ketegangan yang dihadapi sebagai kesenangan. Insting diklasifikan menjadi dua, yaitu insting hidup dan mati. Insting hidup berkaitan dengan tujuan dasar manusia yang memaksakan bertingkah laku konstruktif. Insting mati berkaitan dengan usaha dasar manusia yang memaksakan bertingkah laku destruktif.

Subjek berkecenderungan memiliki insting hidup dan mati untuk memenuhi tujuannya. Subjek berusaha meminang gadis yang disayangi untuk menghindari fitnah akibat kesalahpahaman di masyarakat. Akan tetapi, mendapatkan penekanan atribut yang diperuntukkan. Subjek memaksakan kehendak dan berusaha memenuhi meskipun tidak mudah sehingga menyebabkan kesengsaraan.

Lacan berbicara mengenai hasrat (Faruk, 2014, hal. 193). Hasrat berkaitan dengan keadaan berkekurangan (lack) yang melahirkan keinginan dari ketidaksadaran manusia. Keberadaan manusia dikendalikan dan dipengaruhi oleh ketidaksadaran yang memiliki struktur mirip bahasa. Ketidaksadaran hadir dalam bentuk mimpi, kelakar (senda gurau), keseleo lidah, dan gejala. Bahasa berperan membangkitkan ketidaksadaran. Subjek berusaha mengungkapkan ibu kandung meskipun mendapatkan penekanan. Keberadaan ibu tiri yang memberikan perhatian dan kasih sayang sejak kecil tidak dapat menggantikan.

Subjek merasakan kelengkapan hidup ketika berhasil mewujudkan.

Hasrat didefinisikan sebagai mesin (Hartono, 2007 , hal. 117). Pendefinisian hasrat sebagai mesin bukan mengenai realitas mesin. Hakikatnya mesin hasrat bekerja memproduksi. Hasrat tidak sempurna tanpa batasan mesin. Aliran sebagai produk utama produksi hasrat. Subjek memberontak untuk memperjuangkan hak-haknya yang diabaikan selama ini sehingga mendapatkan kelengkapan hidup dari orang lain.

Deleuze dan Guattari mengkritik pemikiran modernisme, psikoanalisis, dan marxisme tradisional (Hartono, 2007 , hal. 68). Kritik pada modernisme dengan menyelidiki hasrat sebagai energi produktif. Kritik pada psikoanalisis dengan mengembalikan hasrat ke tingkat praimajiner. Kritik pada marxisme tradisional dengan mengemukakan konsep hasrat karena terdapat pemisahan pada tingkat individu dan sosial.

Keempat kritik tersebut yang melahirkan teori skizonalisis dengan membebaskan hasrat. Hasrat dipandang bukan ancaman, melainkan produktif yang menghasilkan keinginan secara terus menerus. Hasrat semakin ditekan melahirkan pemberontakan untuk mewujudkan tujuan meskipun mengabaikan keadaan di sekitar. Hasrat dibiarkan bergerak bebas karena penekanan tidak menghilangkan, melainkan melahirkan. Berdasarkan latar belakang dan teori, penelitian ini memfokuskan pada pendeskirpian hasrat keprdibadian tokoh uatama yang terdapat 
Jurnal Belajar Bahasa, ISSN 2502-5864, E-ISSN 2503-0329

Volume 3, No. 2, September 2018

dalam novel Memburu Matahari karya

masyarakat primitif yang menempatkan Nadjib Kartapati Z.

\section{METODE PENELITIAN}

Metode yang digunakan dalam penelitian ini yaitu deskriptif analitis. Hal tersebut bertujuan untuk menyesuaikan objek penelitian berupa teks sastra. Objek penelitian ini adalah karya sastra novel yang berjudul Memburu Matahari karya Nadjib Kartapati Z sebagai data utama.

Data khusus penelitian ini berupa kata, frasa, kalimat, dan perntayaan yang berhubungan fokus penelitian. Tekni yang digunakan dalam mengumpulkan data, yaitu teknik pembacaan berulang-ulang (rereading) untuk mendalami dan memahami data. Setelah data terkumpul dianalisis dengen teknik hemenerutika objektif, lalu ditelaah, dikelompokkan dan disajikan.

\section{PEMBAHASAN}

Pada bagian ini dipaparkan ihwal hasrat kepribadian tokoh utama yang terdapat dalam novel Memburu Matahari karya Nadjib Kartapati Z. Berdasarkan hasil analisis, tokoh utama dalam novel Memburu Matahari karya Nadjib Kartapati Z tersebut terdapat dua jenis hasrat.

\section{A. Hasrat Paranoid Kepribadian Tokoh Utama dalam Novel Memburu Matahari Karya Nadjib Kartapati Z}

Hasrat paranoid terbentuk dari penekanan sistem-sistem tertentu yang berada di luar diri tokoh utama. Penekanan hasrat dapat terjadi dalam tiga hal, yaitu pertama teritorialisasi dalam masyarakat sebagai mesin sosial yang memiliki sistem-sistem sosial. Sistemsistem sosial, yang meliputi norma, kebiasaan, kepercayaan, tradisi, dan pranata. Kedua teritorialisasi dalam masyarakat barbarian atau despotis menekankan ikatan yang dipimpin penguasa menempatkan diri dalam hubungan dengan dewa maupun Tuhan. Ketiga reteritorialisasi dalam masyarakat kapitalis yang membebaskan hasrat dan menekan kembali.

Hasrat paranoid digambarkan pada Ulfah sebagai isteri untuk mempertahankan hak-haknya yang dirampas karena keteguhan prinsip-prinsip suami dalam novel Memburu Matahari. Ulfah mendapatkan perhatian bukan dari suami, melainkan Bandi. Bandi teman Burhan dan Ulfah bahkan kekasih sebelum menikah. Perhatian Bandi tidak pudar meskipun Ulfah sudah berumah tangga. Hal itu, dapat dilihat pada data berikut.

(1) Oo, Bandi ! Betapa besar perhatianmu terhadapku. Perhatian itulah nilai yang kuagungkan, yang seribu kali tak terbanding dengan nilai nilai anggur dan apel dalam kardus ini. Tiba-tiba saja aku teringat Mas Burhan, suamiku, yang selalu pergi namun tidak pernah sekali juga datang membawa oleh-oleh untukku. Mengingat itu sakit hatiku terasa semakin menekan (Kartapati Z, 2003, hal. 6).

Berdasarkan data (1) tersebut, Ulfah merindukan perhatian dari suami karena mengutamakan pekerjaan sehingga 
Jurnal Belajar Bahasa, ISSN 2502-5864, E-ISSN 2503-0329

Volume 3, No. 2, September 2018

menyebabkan pergolakan batin. Isteri

menghadapi persoalan akan

menginginkan diperhatikan, dimengerti,

mempertimbangkan hal-hal yang

dan dihormati sehingga tidak cukup di- berpotensi buruk. Anak penyemangat nafkahi. Isteri merasakan dihormati ketika suami menanggapi dengan mengakui dan mengutamakan hak-hak, harapan, dan kebutuhan. Ketiga aspek tersebut sebagai kebutuhan mendasar yang hakiki. Kebahagiaan tidak didapatkan dari suami, melainkan orang lain.

Ulfah merasakan kesepian karena belum dikaruniai anak selama empat tahun pernikahan. Apalagi ketidakhadiran suami yang mengutamakan pekerjaan sehingga merasakan tersiksa karena beban yang ditanggung. Ulfah merasakan peranan sebagai isteri tidak utuh dengan ketidakhadiran keluarga kecil. Hal itu, dapat dilihat pada data berikut.

(2) Aku tergeragap bangun. Bangkit dari tidur kemudian duduk di pinggiran ranjang. Tik-tik jam beker di atas meja dalah satusatunya suara yang kedengaran di ruang kamar. Mimpi yang baru saja mengusik lelap tidurku seperti telah menyadarkan diriku dalam suasana sepi yang panjang. Aku memang bukan lagi pengantin baru. Perkawinanku dengan Mas Burhan sudah berjalan empat tahun. Cuma sayang dari perkawinan itu belum membuahkan seorangpun anak. Andaikata malam ini ada seorang bayi di sisiku, barangkali siksaan yang kutanggung tidak sehebat sekarang (Kartapati, 2003:10).

Berdasarkan data (2) tersebut, Ulfah mendambakan kehadiran anak di rumah tangga. Hakikatnya kehadiran Anak penguat hubungan suami isteri ketika hidup sehingga menuntut orang tua giat bekerja untuk memberikan kebahagiaan keluarga. Anak harta berharga dikeluarga patut dididik dan dijaga dengan sepenuh hati agar memiliki kepribadian yang baik dan menggapai cita-cita. Pada filosofi Jawa ketika orang tua berpergian yang ditanyakan bukan harta benda, melainkan anak. Kebahagiaan isteri adalah kehadiran suami dan anak.

Ulfah untuk memperjuangkan hakhaknya mendapatkan penekanan dari suami. Penekanan hasrat ini terjadi dalam teritorialisasi masyarakat primitif sebagai mesin sosial yang memiliki prinsip-prinsip menjadikan dasar berpikir, bertindak, dan berada di masyarakat. Prinsip-prinsip ini bertentangan dikehidupan berumah tangga.

\section{B. Hasrat Skizofrenik Kepribadian Tokoh Utama dalam Novel Memburu Matahari Karya Nadjib Kartapati Z}

Hasrat sebagai mesin produktif yang menghasilkan aliran secara terus menerus pada tokoh utama. Kehadiran hasrat pada realitas sosial dan diri tidak dapat ditekan. Hasrat skizofrenik dikategorikan menjadi dua, yaitu pertama tingkat individu berpotensi merusak bentukan sosial dan membentuk subjek-subjek fasisme. Kedua hasrat skizofrenik tingkat makro berpotensi menginginkan perubahan secara menyeluruh dengan merusak sistem.

Hasrat Skizofrenik tingkat individu digambarkan pada keadaan Ulfah sebagai 

Jurnal Belajar Bahasa, ISSN 2502-5864, E-ISSN 2503-0329

Volume 3, No. 2, September 2018

isteri yang memberontak untuk memperjuangkan hak-haknya selama pernikahan karena keteguhan prinsipprinsip suami dalam novel Memburu Matahari. Hal itu, terbentuk dari hasrat dan pergolakan batin. Hal itu, dapat dilihat pada data berikut.

(3) "Ya, mungkin saja memang gila! Aku mulai menyadari keadanku, kalau kenyataannya hidupku saja memang gila! Aku mulai menyadari keadaanku, kalau kenyataannya hidupku lebih banyak sendiri". "Aku hanya butuh suamiku berada di dekatku, membelai lembut kepalaku dan menyiramkan kasih sayangnya sebagai seorang suami (Kartapati Z, 2003, hal. 10)

Berdasarkan data (3) tersebut, hasrat dan pergolakan batin yang menginginkan suami penyayang, perhatian, dan memahami kebutuhan isteri di setiap waktu. Keresahan dan tersiksa karena suami mengutamakan pekerjaan sehingga rumah tangganya mulai runtuh karena kurang komunikasi. Komunikasi yang utama dalam membangun keharmonisan berumah tangga.

Burhan mengabaikan tanggung jawab sebagai pemimpin rumah tangga dan mengutamakan persoalan sosial. Bahkan, sulit memberontak karena suami menyayangi bahkan mendukung keyakinan ketika berkuliah. Akan tetapi, membutuhkan kehadiran dan merasakan saling memiliki. Hal itu, dapat dilihat pada data berikut.

(4) "Gila!" rutukku tertahan sepenuhnya aku sadari bahwa secara akal pikiran amatlah sulit untuk memberontak suamiku. Adalah kenyataan yang tidak terbantahkan bahwa Mas Burhan sangat mencintaiku. Aku memahami benar alasan-alasanya, bahkan lebih dari itu, pernah mendukung. Kalau sekarang aku memprotes, merasa tersiksa dalam kesendirian, hal itu semata-mata muncul dari naluri dasar seorang wanita. Tidak lebih dan tidak kurang. (Kartapati Z, 2003, hal. 11).

Berdasarkan data (4) tersebut, memprotes karena tidak merasakan naluri sebagai isteri, melainkan orang lain yang merasakan tersiksa dalam kesendirian. Naluri dasar seorang isteri menginginkan perhatian, kasih sayang, dan kebahagiaan dalam berumah tangga. Kebahagiaan tidak ukur dari uang, melainkan perhatian dan kasih sayang yang hakiki.

Hasrat dengan logika produksi Ulfah menyadari tidak berguna membina rumah tangga selama ini karena suami mengutamakan pekerjaan sehingga merasakan kesendirian. Apapun yang terjadi keluarga harus diutamakan karena peranan suami yang utama dibutuhkan di setiap waktu. Hal itu, dapat dilihat pada data berikut.

(5) Ya, mungkin saja memang gila! Aku mulai menyadari keadaanku. Untuk apa bersuami kalau kenyataannya hidupku lebih banyak sendiri? Pertanyaan itu muncul bukan untuk yang pertama kalinya. Andaikata aku teliti mencatatnya, barangkali sebuah buku tulis akan penuh. Namun untuk apa hal-hal itu harus kucatat? Aku tidak butuh catatan! 

Jurnal Belajar Bahasa, ISSN 2502-5864, E-ISSN 2503-0329

Volume 3, No. 2, September 2018

Aku hanya butuh suamiku selalu berada didekatku, membelai lembut kepalaku dan menyiramkan kasih sayangnya sebagai seorang suami (Kartapati Z, 2003, hal. 11).

Berdasarkan data (5) tersebut, Ulfah menginginkan suami yang dapat memberikan kasih sayang karena perhatian salah satu yang dibutuhkan dan isteri dianggap ada dan dihargai sehingga merasakan bahagia. Namun, tidak semua suami memberikan perhatian pada hal-hal kecil dan meremehkan sehingga menyebabkan persoalan rumah tangga. Isteri tidak diperhatikan sehingga merasakan sakit hati. Pada kenyataan terdapat perbedaan pendapat akan kebutuhan perhatian sehingga suami perlu mengetahui dan berusaha mewujudkan yang diharapkan.

Burhan memedulikan masyarakat miskin yang tertindas oleh kekuasaan terpusat. Bahkan, sebagai pemimpin keluarga tidak dapat menafkahi karena bekerja di lembaga pembangungan yang berorientasi perjuangan terkadang tidak digaji. Apalagi kehidupan di Jakarta yang serba mahal. Hal itu, dapat dilihat pada data berikut.

(6) Huh, Ada segumpak rasa muak terlontar kepada suamiku. Kusadari sekarang: tidak sedikit hal yang bertabrakan dalam cara berpikirnya sendiri. Betapa tidak! Mas Burhan selalu berslogan memandirikan orang-orang miskin, akan tetap kapan sebagai kepala keluarga dia mampu memandirikan dirinya ? Dia bekerja hampir-hampir tanpa gaji.
Coba andaikata aku tidak bekerja, darimana rumah tangga ini bias bertahan hidup di Jakarta? (Kartapati Z, 2003, hal. 68).

Berdasarkan data tersebut, kekecewaan pada suami yang tidak dapat menafkahi secara lahir dan batin. Secara ekonomi tidak dapat mengandalkan penghasilan suami dari lembaga yang berorientasi perjuangan sehingga mengharuskan bekerja untuk menambah penghasilan. Keharmonisan rumah tangga terletak pada peran suami isteri dalam menunaikan kewajiban.

Ulfah menyadari suami bukan idaman setiap isteri karena mengutamakan pekerjaan sehingga merasakan sengsara dengan kesepian di setiap waktu. Namun, suami tidak hanya mengabaikan peranan sebagai pemimpin keluarga, melainkan bertindak kasar dengan menuduh berselingkuh dengan Bandi.

\section{SIMPULAN}

Hasrat kerpibadian tokoh utama dalam novel Memburu Matahari karya Nadjib Kartapati Z meliputi dua jenis hasrat. Kedua hasrat paranoid dan skizofenik. Hasrat paranoid terbentuk dari status, tradisi, kepercayaan, keyakinan, nilai, dan ikatan darah (filiasi), sedangkan hasrat skizofrenik, yaitu pertama tingkat individu dan makro. Penelitian menunjukkan bahwa kedua hasrat tersebut merupakan bagian skizoanalisis.

\section{DAFTAR RUJUKAN}

Bertens, K. (1998). Ringkasan Sejarah Filsafat. Yogyakarta: Kanisius. 
Jurnal Belajar Bahasa, ISSN 2502-5864, E-ISSN 2503-0329

Volume 3, No. 2, September 2018

Deleuze, G, \& Guattari, F. (1977). Anti-

Oedipus, Capitalism, and

Schizophrenia. New York.

Faruk. (2014). Metode Penelitian Sastra.

Yogyakarta: Pustaka Pelajar.

Hartono, A. (2007 ). Skizoanalisis Gilles

Deleuze dan Felix Guattari: Sebuah

Pengantar Geneologi Hasrat.

Yogyakarta: Jalasutra.

Indriani, M. Y. (2018). Kepribadian Tokoh

FahUtama dalam Novel Karya Nadjib

Kartapati Z (Kajian Skizoanalisis

Deleuze dan Guattari). Tesis. Universi-

tas Negeri Surabaya (Tidak Dipublikasikan).

Irawan, E. N. (2015). Buku Pintar Pemikiran Tokoh-Tokoh Psikologi dari Klasik sampai Modern. Yogyakarta: Kanisius.

Kartapati Z, N. (2003). Memburu Matahari. Jakarta: Progress. 